\title{
ANGKA PENULARAN HEPATITIS B DARI IBU KE BAYI PADA BAYI YANG MENDAPAT HBIg DI PUSKESMAS KEDATON, PUSKESMAS WAY HALIM DAN PUSKESMAS LABUHAN RATU KOTA BANDAR LAMPUNG TAHUN 2016
}

\author{
Tessa Sjahriani $^{1}$, Debby Ayu Agustin ${ }^{1}$
}

${ }^{1}$ Prodi Pendidikan Dokter, Fakultas Kedokteran Universitas Malahayati

\section{ABSTRAK}

Hepatitis $B$ merupakan penyakit menular yang serius dan umumnya menginfeksi hati disebabkan oleh virus hepatitis B (HBV) yang dapat menyebabkan penyakit akut maupun kronis. Transmisi virus hepatitis B (VHB) dari ibu ke anak (vertikal) dapat terjadi pada masa prenatal atau perinatal (pada saat persalinan atau segera sesudah persalinan) dan merupakan penyebab penularan infeksi hepatitis B (VHB). Untuk mengetahui Angka Penularan Hepatitis B Dari Ibu Ke Bayi Pada Bayi Yang Mendapat HBIg Di Puskesmas Kedaton, Puskesmas Way Halim dan Puskesmas Labuhan Ratu Kota Bandar Lampung Tahun 2016.

Jenis penelitian ini adalah deskriptif dengan menggunakan rancangan cross sectional. Populasi penelitian ini adalah seluruh bayi yang lahir dari ibu dengan HBsAg positif di seluruh Puskesmas Kota Bandar Bandar Lampung pada tahun 2016. Sampel pada penelitian ini sebanyak 30 bayi. Analisis data menggunakan analisis univariat. Penelitian menggunakan 30 bayi yang diberi HBIg, diketahui distribusi frekuensi angka penularan hepatitis $B$ dari ibu ke bayi pada bayi yang mendapatkan HBIg dari 30 bayi menunjukkan $83.3 \% \mathrm{HBsAg}(-)$ yang artinya status infeksi HBV pada responden sebagian besar negatif, dengan usia terbanyak usia 18 bulan sebesar 40,0\% dan paling sedikit pada usia 11 bulan sebesar $23,3 \%$ serta jenis kelamin bayi paling banyak berjenis kelamin laki-laki sebesar $56,7 \%$. Dimana seluruh bayi memiliki riwayat pemberian HBO. 83,3\% Angka penularan hepatitis B dari ibu HBsAg (+) ke bayi pada bayi yang mendapatkan HBIg menunjukkan hasil HBsAg (-).

Kata Kunci: Hepatitis B, HBIg

\section{PENDAHULUAN}

Hepatitis B merupakan penyakit menular yang serius dan umumnya menginfeksi hati disebabkan oleh virus hepatitis B (HBV) yang dapat menyebabkan penyakit akut maupun kronis. HBV merupakan masalah kesehatan global, diperkirakan sekitar dua miliar penduduk dunia pernah terkena virus hepatitis $B$. virus hepatitis $B$ telah menginfeksi lebih dari 350 juta orang di dunia atau kurang lebih 5\% populasi dunia (Neal A et al, 2013).

HBV telah menjadi penyakit endemis diberbagai negara di dunia termasuk Indonesia. Indonesia merupakan negara dengan endemisitas tinggi Hepatitis B terbesar kedua di negara South East Asian Region (SEAR) setelah Myanmar. Berdasarkan data yang dikeluarkan oleh World Health Organization (WHO) diperkirakan bahwa lebih dari dua miliar orang sudah terinfeksi virus hepatitis $B$, dimana 360 juta orang terinfeksi hepatitis $B$ kronis dan 240 juta orang terdapat di Asia, termasuk Indonesia. Indonesia adalah negara endemis tinggi Hepatitis B dengan prevalensi HBsAg positif di populasi antara $7-10 \%$. Pada kondisi seperti ini, transmisi vertikal dari ibu yang berstatus HBsAg positif ke bayinya memegang peranan penting. $\mathrm{Di}$ lain pihak, terdapat perbedaan patofisiologi antara infeksi Hepatitis B yang terjadi pada awal kehidupan dengan infeksi Hepatitis B yang terjadi pada masa dewasa. Infeksi yang terjadi pada awal kehidupan, atau bahkan sejak dalam 
kandungan (transmisi dari ibu dengan HBsAg positif), membawa resiko kronisitas sebesar 80-90\%. Untuk provinsi Lampung jumlah penduduk yang terinfeksi hepatitis B $(14,8 \%)$ (Kemenkes RI, 2016).

Transmisi virus hepatitis B (VHB) dari ibu ke anak (vertikal) dapat terjadi pada masa prenatal atau perinatal (pada saat persalinan atau segera sesudah persalinan) dan merupakan penyebab penularan infeksi hepatitis B (VHB). Sekitar $70-90 \%$ dari penularan virus ini berkembang menjadi infeksi kronis dengan resiko terjadinya sirosis hati dan karsinoma hepatoseluler (HCC). Ibu yang memiliki hepatitis $B$ antigen " $e$ " positif dapat menularkan hepatitis $B$ secara perinatal kepada bayinya. HBeAg merupakan salah satu penanda untuk infeksi virus hepatitis B dan berhubungan dengan tingkat infektivitas yang tinggi. Resiko infeksi kronik dari ibu $\mathrm{HBeAg}$ positif kepada bayinya sebesar $85 \%$ sampai $90 \%$, sebaliknya pada ibu HBeAg negatif sebesar $5 \%$ sampai $31 \%$ (Snyder J.D \& Larry K.P, 2012).

WHO merekomendasikan pelaksanaan vaksinasi disesuaikan dengan program nasional. Namun, pada negara yang proporsi infeksi VHB perinatal yang tinggi pemberian dosis pertama vaksin diberikan kurang dari 24 jam setelah persalinan dengan minimum interval antara 2 dosis diberikan dalam 4 minggu. Di Indonesia, berdasarkan rekomendasi Ikatan Dokter Indonesia, dosis pertama vaksin hepatitis B diberikan 12 jam setelah persalinan bersamaan dengan pemberian imunoglobulin (HBIg) bila ibu $\mathrm{HBsAg}$ positif (Ismalita, 2003).

Vaksinasi merupakan pencegahan yang aman dan efektif pada infeksi hepatits B. Saat ini beberapa strategi telah dikembangkan untuk mengurangi transmisi infeksi dari ibu kepada bayi, selain diberikan vaksinasi juga diberikan imunoglobulin (HBIG). Penelitian kohort di Taiwan menunjukkan penurunan insiden hepatoseluler karsinoma pada anak yang berumur antara 6-9 tahun setelah dilakukan vaksinasi, yaitu dari 0,52 menjadi 0,13 per-100.000 (Chen $\mathrm{H}$ et al, 2004).
Vaksinasi hepatitis B merangsang pembentukan hepatitis $B$ surface antibody (anti $\mathrm{Hbs}$ ), yang seiring dengan waktu mengalami penurunan. Beberapa penelitian menunjukkan bahwa titer anti-Hbs masih memberikan efek proteksi pada 2-4 tahun, bahkan sampai 10 tahun setelah vaksinasi primer. Pada beberapa penelitian didapatkan penurunan titer anti-HBs setelah vaksinasi (Neal A et al, 2013).

Masalah Hepatitis yang paling rawan ada pada wanita hamil. dr. Rino, Ketua Perhimpunan Peneliti Hati Indonesia (PPHI), mengatakan bahwa Hepatitis B ada pada anak karena ia masuk melalui jalan lahir ibunya. Dianjurkan agar wanita melakukan pemeriksaan hepatitis, lebih awal lebih baik. Sekitar 3,9\% ibu hamil merupakan pengidap hepatitis dengan risiko transmisi maternal kurang lebih sebesar $90 \%$ anak yang tertular secara vertikal dari ibu dengan HBsAg (+) selama tahun pertama kehidupan akan berkembang mengalami Hepatitis B kronis $90 \%$ dan akan menjadi carrier. Anak-anak yang terinfeksi sebelum usia 6 tahun mengembangkan infeksi kronis sebesar 30-50\%. Anak tersebut 25\% akan mati dari penyakit hati kronis atau kanker hati. Maka pencegahan penularan secara vertikal merupakan salah satu aspek yang paling penting dalam memutus rantai penularan Hepatitis B (Konsensus PPHI, 2006).

Saat ini di Propinsi Bandar Lampung peneltian mengenai evaluasi bayi dari ibu HBsAg positif setelah pemberian vaksin HBO $<12$ jam saja atau dengan HBIg $<12$ jam masih jarang. Oleh karena itu, peneliti tertarik untuk melakukan penelitian tentang angka penularan Hepatitis B dari ibu ke bayi pada bayi yang mendapatkan HBIg di Puskesmas Kedaton, Puskesmas Way Halim dan Puskesmas Labuhan Ratu Kota Bandar Lampung Tahun 2016.

\section{METODE PENELITIAN}

Jenis penelitian ini adalah deskriptif dengan menggunakan rancangan cross sectional. Populasi penelitian ini adalah seluruh bayi yang lahir dari ibu dengan HBsAg positif di seluruh Puskesmas Kota Bandar Bandar Lampung pada tahun 2016. Sampel pada penelitian ini 
sebanyak 30 bayi. Analisis data menggunakan analisis univariat.

Kriteria inklusi

1) Bayi yang lahir dari ibu HBsAg positif yang diberi HBIg di Puskesmas Kedaton, Puskesmas Way Halim dan Puskesmas Labuhan Ratu Kota Bandar Lampung dengan HBsAg positif.

2) Bayi yang lahir dari ibu HBsAg positif yang diberi HBIg di Puskesmas
Kedaton, Puskesmas Way Halim dan Puskesmas Labuhan Ratu Kota Bandar Lampung dengan HBsAg negatif.

Kriteria eksklusi

1) Ibu hamil di Puskesmas Kedaton, Puskesmas Way Halim dan Puskesmas Labuhan Ratu Kota Bandar Lampung dengan HBsAg negatif.

2) Bayi yang didiagnosis hepatitis lain.

HASIL PENELITIAN

Karakteristik Responden

Tabel 1.Distribusi FrekuensiKarakteristik Responden Di Seluruh Puskesmas Kota Bandar Lampung Tahun 2016.

\begin{tabular}{|c|c|c|c|}
\hline No & Karakteristik & $\begin{array}{l}\text { Frekuensi } \\
(\mathbf{N})\end{array}$ & $\begin{array}{c}\text { Persentase } \\
(\%)\end{array}$ \\
\hline \multirow[t]{7}{*}{1} & Pendidikan ibu & & \\
\hline & a. Tidak sekolah & 3 & 10,0 \\
\hline & b. SD.Sederajat & 3 & 10,0 \\
\hline & c. SMP & 8 & 36,7 \\
\hline & d. SMA & 13 & 43,3 \\
\hline & e. Diploma/Sarjana & 3 & 10,0 \\
\hline & Jumlah & 30 & 100 \\
\hline \multirow[t]{6}{*}{2} & Usia Bayi & & \\
\hline & a. 11 bulan & 7 & 23,3 \\
\hline & b. 15 bulan & 4 & 13,3 \\
\hline & c. 18 bulan & 12 & 40,0 \\
\hline & d. 19 bulan & 2 & 6,7 \\
\hline & e. 24 bulan & 5 & 16,7 \\
\hline & Jumlah & 30 & 100 \\
\hline \multirow[t]{3}{*}{3} & Jenis kelamin bayi & & \\
\hline & a. Laki-laki & 17 & 56,7 \\
\hline & b. Perempuan & 13 & 43,3 \\
\hline \multirow{4}{*}{4} & Jumlah & 30 & 100 \\
\hline & Riwayat pemberian $\mathrm{HBO}$ & & \\
\hline & a. Diberikan & 30 & 100 \\
\hline & b. Tidak diberikan & 0 & 0 \\
\hline & Jumlah & 30 & 100 \\
\hline
\end{tabular}

Hasil penelitian yang dijelaskan pada tabel 1. diatas didapatkan dari 30 ibu dengan hasil HBsAg (+) bahwa sebagian besar $43.3 \%$ pendidikan terakhir ibu dari responden adalah SMA sedangkan persentase terkecil 10,0\% pada kelompok pendidikan tidak sekolah, SD, SMP dan diploma/sarjana. Usia bayi sebagian besar menunjukkan usia 18 bulan sebesar $40,0 \%$ serta jenis kelamin bayi paling banyak berjenis kelamin laki-laki sebesar $56,7 \%$. Seluruh bayi memiliki riwayat pemberian HBO. 


\section{Angka Penularan Hepatitis B Dari Ibu Ke Bayi Pada Bayi Yang Mendapat HBIg}

\section{Tabel 2. Distribusi Frekuensi Angka Penularan Hepatitis B Dari Ibu Ke Bayi Pada Bayi Yang Mendapat HBIg.}

\begin{tabular}{llcc}
\hline No & $\begin{array}{l}\text { Penularan HBsAg pada bayi } \\
\text { yang diberi HBIg }\end{array}$ & Frekuensi (N) & Persentase (\%) \\
\hline 1 & HBsAg $(-)$ & 25 & 83,3 \\
2 & HBsAg $(+)$ & 5 & 16,7 \\
\hline \multicolumn{2}{r}{ Jumlah } & 30 & 100 \\
\hline
\end{tabular}

Hasil penelitian yang dijelaskan pada tabel 2 . diatas menunjukkan bahwa seluruh responden memiliki riwayat pemberian HBIg. Pemberian HBIg dari 30 responden sebesar $25(83.3 \%)$ bayi dari ibu HBsAg positif setelah mendapatkan HBIg menunjukan hasil HBsAg (-) yang artinya status infeksi HBV pada responden negatif. Hal ini membuktikan bahwa sebagian besar bayi yang mendapatkan HBIg < 12 jam menunjukan hasil negatif.

\section{PEMBAHASAN \\ Karakteristik Responden}

Hasil penelitian didapatkan dari 30 bayi dari ibu dengan hasil HBsAg (+) bahwa rata-rata pendidikan ibu sebagian besar $43.3 \%$ pendidikan terakhir ibu dari responden adalah SMA, usia bayi menunjukkan terbanyakpada usia 18 bulan sebanyak 12 bayi $(40,0 \%)$ dan paling sedikit usia 19 bulan sebanyak 2 bayi $(6,7 \%)$ serta jenis kelamin bayi paling banyak berjenis kelamin laki-laki sebanyak 17 bayi $(56,7 \%)$. Seluruh bayi memiliki riwayat pemberian HBO.

Laki-laki mempunyai kadarserum IgM dan IgG yang lebih rendah. Responimun yang berbeda antara lakilaki dan perempuandipengaruhi pula oleh hormon steroid seks sepertiestrogen, progesteron, dan testosteron yang berbedapada masingmasing jenis kelamin. Seiring dengan peningkatan umur, maka akan terjadi penurunan kadar anti-HBs. Selain jenis kelamin, jadwal imunisasi, beberapa faktor yang mempengaruhi kadar antiHBs setelah vaksinasi, seperti status imun, genetik, kualitas dan kuantitas vaksin, penyakit keganasan, dan penyakit kronik (Banatvala J, 2003).
Penurunan kadar anti-Hbs terjadi seiring dengan peningkatan umur. Beberapa penelitian menyarankanpemberian vaksinasi hepatitis B yang lebih awal, agarmendapatkan kadar anti-Hbs $=10$ $\mathrm{mIU} / \mathrm{ml}$ padainterval $79 \%-85 \%$ setelahvaksinasi.

\section{Analisis Angka Penularan Hepatitis B Dari Ibu Ke Bayi Pada Bayi Yang Mendapat HBIg}

Hasil penelitian dari 30 catatan kartu monitoring bayi dari ibu dengan HBsAg didapatkan penularan infeksi hepatitis B pada bayi yang dilahirkan dari ibu HBsAg positif hanya sebanyak 5 bayi $\quad(16,7 \%)$ Hasil penelitianmendukung hasil penelitian Dwivedi, M. Et al(2011) menjelaskan bahwa penularan vertikal dari ibu dengan HBsAg positif sebesar 20\% (1 dari 5) (Dwivedi, 2011). Hasil penelitian sesuai dengan literatur yang menyatakan bahwa $10 \%$ bayi yang lahir dari wanita dengan HBsAgpositif terinfeksi HBV (American College of Obstetricians and Gynecologists, 2015).

Hasil penelitian serupa dengan hasil penelitian Shepard CW et al(2016) dengan hasil bahwa persentase ibu HBsAg(+) untuk penularan vertikal dari 48 responden yang menunjukan $\mathrm{HBsAg}(+)$ pada bayi yang telah diberikan HBIg ketika lahir sebanyak 1 orang $(2,1 \%)$ hal ini dikarenakan risiko infeksi perinatal adalah 5-20 \% bayi yang lahir dari ibu denganHBsAg positif dan $70-90 \%$ jika ibu HBeAg (+) (Shepard CW et al, 2016).Menurutpenelitian Kang G et al (2015) tentang kemampuan efikasi pemberian vaksin hepatitis $B$ saja 
sebesar $75 \%$, kemampuan efikasi diberi HBIg saja adalah $71 \%$,sedangkan kemampuan efikasi diberi vaksin hepatitis B dan HBIg adalah 94\%.Di beberapa daerah di China, oleh karena itu vaksinasi universal saja masih merupakan pengobatan yang optimal.

Vaksin HB dapat ditoleransi denganbaik dan menimbulkan respons kekebalan yang baik pada bayi. Estimasi efikasivaksin hepatitis B yaitu $50-90 \%$. Pemberian vaksinasi hepatitis $B$, sepertiyang ada di Gambia dan program model di Kamerun dan Kenya. Pada 96\% bayi,hepatitis B Imunisasi menimbulkan proteksi yang cukup tinggi. Hasil dari programserologis sampel anak yang divaksinasi menunjukkan bahwa vaksinasi efektifdalam mengurangi jumlah anak yang terus terinfeksi. Uji klinis vaksin hepatitisB telah menunjukkan kemanjuran yang protektif antara 85 - 95\% dalam mencegah infeksi HBV.

Program vaksinasi massal berhasil mengurangi tingkat pembawa dan prevalensi HBV. Vaksin saja kemungkinn cukup untukmencegah penularan $\mathrm{HBV}$ pada neonatus $\mathrm{HBsAg}$ positif (Kang, G et al, 2015).Hasil penelitian mendukung hasil penelitian Borgia G et al (2012) yang menyatakan bahwa bayi yang lahir dari ibu HBsAg positif yang diberikan HBIg < 12 jam setalah lahir, mendapatkan hasil HBsAg negatif setalah monitoring 3 tahun kemudian (Borgia $\mathrm{G}$ et al, 2012). Bila imunisasi diberikan segera setelah lahir, hanya $53-68 \%$ yang akan mengalami serokonversi 1 bulan pasca imunisasi ketiga. Penundaan imunisasi akan meningkatkan serokonversi mencapai $90 \%$, tetapi dengan lama proteksi yang belum diketahui. Keberhasilan imunisasi tergantung beberapa faktoryaitu status imun, faktor genetik penjamu serta kualitas dan kuantitas vaksin (Ismalita, 2003).

Imunisasi adalah cara efektif mengontrol infeksi VHB sampai saat ini. Prevalensi infeksi hepatitis B kronik, hepatitis B fulminan, dan karsinoma hepatoseluler menunjukkan penurunan bermakna setelah vaksinasi hepatitis $B$. Penelitian kohort di Taiwan menunjukkan penurunan insidens hepatoseluler karsinoma pada anak yang berumur antara 6-9 tahun setelah dilakukan vaksinasi, yaitu dari 0,52 menjadi 0,13 per-100.000 (Chen $\mathrm{H}$ et al, 2004).Vaksinasi hepatitis $B$ merangsang pembentukan hepatitis $B$ surface antibody (anti Hbs), yang seiring dengan waktu mengalami penurunan. Beberapa penelitian menunjukkan bahwa titer anti-Hbs masih memberikan efek proteksi pada 2-4 tahun, bahkan sampai 10 tahun setelah vaksinasi primer (Neal A et al, 2013).

Hasil penelitian serupa dengan penelitian yang dilakukan oleh Lin dkk memperlihatkan penurunan efek proteksi anti-Hbs pada 951 anak tanpa vaksinasi booster, yaitu $71,1 \%$ pada umur 7 tahun dan $37,4 \%$ pada umur 12 tahun (Lin $Y$ et al, 2003). Pada penelitian yang dilakukan di Alaska, $88 \%$ (182 dari 208) anak yang divaksinasi dengan hepatitis $B$ setelah lahir pada umur 4 tahun tidak ditemukan anti-Hbs (Petersen $\mathrm{K}$ et al, 2004). Sedangkan penelitian yang dilakukan di Nederland, follow up yang dilakukan setelah 15 tahun, 30\% tidak terdeteksi anti-Hbs (Banatvalaet al, 2003). Penelitian yang dilakukan olehJafarzadeh dkk, mendapatkan kadar protektif antiHbs pada 47,9\% anak setelah 10 tahun imunisasi hepatitis B. Pada beberapa penelitian didapatkan penurunan titer anti-HBs setelah vaksinasi (Jafarzadeh A et $a l, 2006)$.

Pada beberapa penelitian menunjukkan adanya respon anamnestik pada kadar anti-HBs yang rendah maupun yang tidak terdeteksi. Di lain pihak, produksi anti-HBs dari sel B sirkulasi menandakan memori imun. Setelah injeksi vaksin hepatitis B, titer antiHBs meningkat secara dramatis. Adanya limfosit B memori setelah vaksinasi hepatitis $B$ mengindikasikan terdapat sel B sirkulasi yang memproduksi anti-HBs in vitro, bahkan pada keadaan tidak terdeteksi anti-HBs di serum dapat disertai peningkatan yang cepat dari anti-HBs setelah dosis booster (Neal A et al, 2013).

Penurunan kadar anti-Hbs terjadi seiring dengan peningkatan umur. Pada 
penelitian saya karakteristik responden dari usia 11-24 bulan yang telah mendapatkan vaksin HBO dan HBIg < 12 jam serta hepatitis B secara 3 kali. Paling banyak terdapat pada usia 18 bulan sebesar $40,0 \%$ dan berjenis kelamin laki-laki 56,7\%.

Hasil penelitian ini masih banyak keterbatasan dikarenakan waktu penelitian yang singkat serta data yang masih kurang lengkap dari pihak yang berkaitan serta penelitian dilakukan dengan cara pengambilan data sekunder dikarenakan keterbatasan biaya dan waktu.

\section{Kesimpulan}

1. Distribusi frekuensi pendidikan ibu sebagian besar dengan pendidikan terakhir ibu SMA sebanyak 13 ibu (43.3\%), usia bayi menunjukkan terbanyak pada usia 18 bulan sebanyak 12 bayi $(40,0 \%)$ dan paling sedikit usia 19 bulan sebanyak 2 bayi $(6,7 \%)$ serta jenis kelamin bayi paling banyak berjenis kelamin laki-laki sebanyak 17 bayi $(56,7 \%)$. Seluruh bayi memiliki riwayat pemberian $\mathrm{HBO}$.

2. Distribusi frekuensi angka penularan hepatitis $B$ dari ibu ke bayi pada bayi yang mendapatkan HBIg dari 30 bayi menunjukkan 25 bayi (83.3\%) HBsAg (-) yang artinya status infeksi HBV pada bayi sebagian besar negatif.

\section{DAFTAR PUSTAKA}

American College of Obstetricians and Gynecologists. (2015). ACOG Practice Bulletin No. 86: Viral hepatitis in pregnancy. Obstetrics and gynecology, 110(4), 941.

Arief, S., 2012. Hepatitis Virus. In: Juffrie, M.,et al., ed. Buku Ajar Gastroenterologi -Hepatologi. $3^{\text {rd }}$ ed. Jakarta: IDAI, 285305.
Banatvala J, Van Damme P. (2003). Hepatitis $B$ vaccine: Do we need boosters? . J Viral Hepat 2003;10:1-6.

Borgia Guglielmo, Maria Aurora Carleo, Givanni Battista Gaeta, Ivan Gentile. (2012). Hepatitis B In Pregnancy. World Journal of Gastroenterology. Vol. 34. ISSN : 1007-9327.

Chen $\mathrm{H}$, Chang $\mathrm{C}$, Wong $\mathrm{M}$, Huang $\mathrm{F}$, HC L, Lin Cd. (2004). Pediatric fulminant hepatic failure in endemic areas of hepatitis $B$ infection: 15 years after universal hepatitis $B$ vaccination.

Hepatology;39:58-63.

Dahlan S, (2014). Statistik Untuk Kedokteran dan Kesehatan. Salemba Medika. Jakarta.

Dwivedi, M., Misra, S. P., Misra, V., Pandey, A., Pant, S., Singh, R., \& Verma, M. (2011). Seroprevalence of hepatitis $B$ infection during pregnancy and risk of perinatal transmission

Fan, H.L., et al., 2012. Predictors of the Outcomes of Acute on Chronic Hepatitis B Liver Failure. World Journal of Gastroenterology , 18 (36): 5078-5083.

Franco, E., et al., 2012. Hepatitis B: Epidemiology and Prevention in Developing Countries. World Journal of Hepatology , Vol.4: 74-80.

Geeta, M.G., \& Riyaz, A., 2013. Prevention of Mother to Child Transmission of Hepatitis B Infection. Indian Pediatrics, Vol.50: 189-192.

Ghanaei, R.M., Joukar, F., Souti, F., \& Roushan, Z.A., 2013. Knowledge and Attitude of Medical Students Toward 
Hepatitis B and C Infections. International Journal of Clinical and Experimental Medicine , 6 (3): 197-205.

Ismalita. (2003). Pemberian Imunisasi Hepatitis B pada Bayi Prematur. Sari Pediatri. Vol. 4: No. 4 : 163-167

Infodatin. (2014). Situs \& Analisis Hepatitis. Jakarta : Pusat Data dan Informasi Kementrian Kesehatan Republik Indonesia.

Jafarzadeh A, SJ M. (2006). Persistence of anti-HBs antibody and immunological memory in children vaccinated with hepatitis $B$ vaccine at birth. J Ayub Med;18:1-9.

Kang, G., Ma, F., Chen, H., Yang, Y., Guo, S., Wang, Z., \& Zhang, L. (2015). Efficacy of antigen dosage on the hepatitis $B$ vaccine response in infants born to hepatitis B-uninfected and hepatitis B-infected mothers. Vaccine, 33(33), 4093-4099

Kemenkes RI. (2016). Pedoman Pengendalian Hepatitis Virus. Jakarta: Kementrian Kesehatan Republik Indonesia

Konsensus PPHI. (2006). Panduan Tata Laksana Infeksi Hepatitis B Kronik. Jakarta : Perhimpunan Peneliti Hati Indonesia.

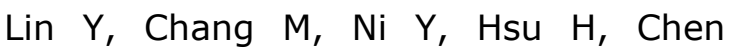
D.(2003). Long term immungenicity and efficacy of universal hepatitis $B$ virus vaccination in Taiwan. J Infect Dis $2003 ; 187: 134-8$.

Manatvala J, Van Damme P. (2003). Hepatitis $B$ vaccine- do we need boosters?. J Viral Hepatology ;1: 1-6.
Neal A. Halsey MD, Jon S. Abramson MD, Mrgaret C. Fisher ND et al. (2013). Immunization of Aldolesants Recommendation of The Advisory Committee On Immunization Practice, The American Academy of Pediatrics, The American Academy of Family Physicians, And The American Medical Association. PEDIATRIC: Vol. 99: No. 3.

Notoatmodjo, S., 2010. Metodologi Penelitian Kesehatan. Jakarta: Rineka Cipta

Petersen K, Bulkow L, McMahon B, Zanis $C$, Getty $M$, Peters $H$, dkk. (2004). Duration of hepatitis $B$ immunity in low risk children receiving hepatitis $B$ vaccinations from birth. J Pediatr Infect Dis ;23:650-6.

Price, S.A., \& Wilson, L.M., (2005). Patofisiologi Konsep Klinis Proses-Proses Penyakit. Edisi 6: EGC: Jakarta.

Satgas Imunisasi IDAI. (2000). Jadwal imunisasi rekomendasi IDAI. SarinPediatri (2) 1: 43-7.

Shepard, C. W., Simard, E. P., Finelli, L., Fiore, A. E., \& Bell, B. P. (2016). Hepatitis B virus infection: epidemiology and vaccination. Epidemiologic reviews, 28(1), 112-125

Snyder D John and Larry K. Pickering. (2012). Haptitis A sampai E. Dalam: (terjemahan) Nelson WE dkk (editor). Buku teks ilmu kesehatan anak Nelson. Edisi ke15. Vol. 2, Jakarta: EGC; hlm. $1120-1123$.

WHO, 2002. Health Care Worker Safety. World Health Organization

WHO, 2012. Hepatitis B. World Health Organization 